Business and Economics Research Journal

Volume 8 Number 42017

pp. $785-795$

ISSN: $1309-2448$

DOI Number: 10.20409/berj.2017.83

\title{
Sözlü Saldırganlığın Örgütsel Bağlılığa Etkisi ve Algılanan Arkadaş Desteğinin Aracılık Rolü: Kazakistan Örneği ${ }^{1}$
}

\begin{abstract}
Mustafa Karaca ${ }^{\mathrm{a}}$
Öz: Bu çalışmanın amacı, algılanan arkadaş desteği aracı (mediating) role sahipken sözlü saldırganlığın örgütsel bağlılı̆a etkisini incelemektir. Araşttrmanın örneklemini Kazakistan'da sağlık alanında faaliyet gösteren kamu kurumlarındaki 1265 kişi oluşturmaktadır. Araştrmanın amacına yönelik olarak kurulan model çerçevesinde oluşturulan hipotezlerin testi için hiyerarşik regresyon analizleri uygulanmıştır. Araştırma bulgularına göre sözlü saldırganlığın hem örgütsel bağlıık hem de arkadaş desteğini etkilediği ortaya çıkmış, ilave olarak da arkadaş desteğinin bu ilişkide kısmi aracı role sahip olduğu tespit edilmiştir. Araştrma Türkiye ve Kazakistan arasında gerçekleștirilen disiplinlerarası bir çalışma niteliğindedir.
\end{abstract}

Anahtar Sözcükler: Sözlü Saldırganlık, Örgütsel Bağlılık, Algılanan Arkadaş Desteği, Aracı Etki, Kazakistan

JEL Sınıflandırması: M12, M54

\section{The Effect of Verbal Aggressiveness to Organizational Commitment and Mediating Role of Perceived Peer Support: Kazakhstan Example}

\begin{abstract}
The aim of this study is to examine the effect of verbal aggressiveness on organizational commitment while the perceived peer support is the mediator. For this aim, a survey study, which includes 1265 participants from a public health center in Kazakhstan, is used. For the aim of the study, we used hierarchical regression analyses. The results indicate that verbal aggressiveness has a direct effect on organizational commitment and perceived peer support. In addition to this result, it was also found that perceived peer support has a partial mediating role on this relationship. This research has been studied in between Kazakhstan and Turkey. And it is an interdisciplinary study.
\end{abstract}

Keywords: Verbal Aggressiveness, Organizational Commitment, Perceived Peer Support, Mediating Effect, Kazakhstan

JEL Classification: M12, M54

asst. Prof., PhD., Inonu University, Faculty of Communication, Department of Public Relations and Publicity, Malatya, Turkiye, mkaraca@inonu.edu.tr 


\section{Giriş}

Örgütler, belirli amaçlar peşinde koşan yüksek düzeyde rasyonel yapılardır ve burada kararlar faydayı maksimize etme ilkesine dayalı olarak alınmaktadır. Bunun da ötesinde, kararları alan bireylerin, açık ve genel bir amaç ile gerekli öngörüye sahip oldukları da düşünülürse, örgütün bugünü ve geleceği açısından doğru tercihleri ve sonuçları ortaya koyabilecekleri düşünülmektedir (Robbins, 1990). Ancak gerçek hayatta ve acımasız rekabet ortamında düzen, her zaman bu şekilde işlememekte ve örgütlerde rasyonel olmayan davranışlar da sergilenebilmektedir. Çünkü, günümüz açısından önemli bir kaynak olan insan hem yönetilmesi hem de elde tutulması değerli bir faktör haline gelmiştir.

Kabiliyetleri, kaynakları, ilişkileri ve kararları kapsayan rekabetçi avantaj, bir firmanın firsatları kendi lehine kullanmasına ve sektöründeki tehlikelerden kurtulmasına imkân sağlamaktadır (Hofer ve Schendel 1978). Günümüz hızla değişen küresel ekonomik dünyasında Porter (1985)'ın da belirttiği üzere, bilgiye dayalı yönetim anlayışının daha da önem kazanmasıyla birlikte bir firmanın tüm süreçlerinde insan kaynaklarının en önemli girdi olduğunun farkına varılmış ve insan kaynaklarının yönlendirilmesinin ve yönetilmesinin optimize edilmesi ile bir firmanın sürdürülebilir rekabetçi avantaj elde edeceği vurgulanmıştır.

Ortak aklı ön plana çıkaran yeni çalışma hayatında, kurumların sahip oldukları insan ve sosyal sermayesi çok önemlidir. Bu sermayeler ise karşılıklı anlayış, ortak değerler ve davranışlardan oluşmaktadır. İnsan ve sosyal sermayenin baskın bir öğesi olan ilişkiler arası güven, ilişkileri bir arada tutan yapıştrıcı gibidir. İşletme çıktılarının artırılmasında örgüt üyelerinin algıları önemli bir yer tutmaktadır. Bu nedenle çalışanların iş ortamlarını, kararların adil olarak verildiği ve uygulandığı bir yer olarak algılamasının önemi büyüktür (Shalley vd., 2004). Bu kapsamda çalışanlar açısından daha mutlu, örgütüne bağlı, arkadaşlarından destek gördüğü bir iklimin oluşturulması ile hem kişiler arası güven artacak hem de çalışanlar daha çok işlerine bağlı hale geleceklerdir. Çünkü bu tür bir uygulama ve iklim sayesinde hem işgören/çalışanlar hem de örgüt açısından uzun dönemli sürdürülebilir bir büyüme sağlanacaktır. Bu kapsamda özellikle bu tarz bir kültür oluşturulmasında birer rol model olarak örgütlerde yönetici pozisyonunda olan kişilerin tutum ve davranışları büyük önem kazanmaktadır. Çünkü bireyler arası ilişkilerde yöneticilerin ilişkisel rolü de çok önemlidir.

Çalışanın iş hayatı ve geri kalan iş dışı yaşamı arasında bir denge kurması konusundaki zorluk, literatürde önemli oranda artan bir ilgide çalışmalara konu olmaya başlamıştır (Wayne vd., 1997; Tsui vd., 1997; Lambert, 2000; Stinglhamber ve Vandenberghe, 2003). Çalışanın organizasyonel desteği hissetmesini ölçmek, iş yaşamında önemli konular arasında yer almaktadır ve bu konu hem bireysel hem de organizasyonel düzeyde önem arz etmektedir. Bu nedenle, Algılanan Arkadaş Desteği (Perceived Peer Support), çalışanın kendi iş-hayat gereksinimlerini, içinde bulunduğu organizasyondaki iş arkadaşları tarafindan ne kadar desteklendiğini ölçmek için geliştirilmiştir (Jahn vd., 2003). Bu yapı, çalışanların organizasyonun kendilerine yardım etmeye verdiği değer ve iyi olmalarına verdiği önem (Eisenberger vd., 1986; Coyle-Shapiro ve Conway, 2005) ile ilgili global inançları olarak tanımlanan Algılanan Organizasyon Desteğinin (Perceived Organizational Support) bir alt setidir.

Literatürde her ne kadar sözlü saldırganlığın negatif etkisinden bahsedilse de bütün yıkıcı etkisine rağmen sözlü saldırganlık kişilerarası şiddete ve fiziksel saldırganlığa engel olabilmektedir (Infante, 1989). Burada kişinin kızgınlığını bir anlamda sözlü olarak dışa vurmak suretiyle kendisini yatıştırmasından bahsedilmektedir. Sözlü olarak karşısındaki bireye saldıran kişinin fiziksel şiddete daha az başvurduğu ifade edilmektedir (Carey ve Mongeau, 1996). Tabi ki bu durum da normal iletişim sürecinde istendik bir davranış değildir lakin fiziksel şiddete göre daha az yıkıcı olduğu aşikârdır.

Bu çerçevede çalışmanın amacı literatürde sınırlı sayıda araştırmalara konu olan sözlü saldırganlık ve etkileri konusunda teorik bir çerçeve sunmak ve örgütlerde sözlü saldırganlığın örgütsel bağlılık ve algılanan arkadaş desteği üzerindeki etkilerini inceleyip, algılanan arkadaş desteğinin aracı bir role sahip olup olmadığını tespit etmektir. Bu kapsamda çalışmanın amacına yönelik teori ve hipotezlerin oluşturulması aşamasında öncelikle literatür incelenmiş ve ilgili literatür kapsamında da çalışmanın hipotezleri oluşturulmuştur. Metodoloji bölümünde, hipotezleri test etmek için kullanılan örneklem ve yöntem verilerek elde edilen sonuçlar sunulmuştur. Son bölümde ise çalışma sonuçlarının özeti, çalışmanın kısıtları, üstünlükleri ve zayıflıkları verilerek, gelecek çalışmalar için çeşitli önerilerde bulunulmuştur. 


\section{Literatür Araştırması Ve Hipotezlerin Oluşturulması}

Kanaatimizce birçok firma için sürdürülebilir rekabet avantajını sağlamak adına geleneksel yol olan; ölçek ekonomisi, patent koruması, sermaye girişi ve rekabet denetlemesi gibi kavramların artı geride kalmıştr. Yeni paradigmada, yeni bir rekabetçi avantaj kaynağına olan ihtiyaç artmış ve strateji, bir organizasyonun insan kaynaklarının rolü ve insan kaynaklarının firma performansı ile ilişkisi hakkındaki geleneksel anlayışa meydan okumaya başlayarak bilgi donanımlı insan kaynağının daha mutlu, huzurlu, güvenli ve örgütüne daha bağlı bir iklimdeki bakış açısına doğru evrilmiştir.

Globalleşme ve beraberindeki sürekli değişim talebi ile inovasyon, uyarlanabilirlik, hız ve iş alanının önemli özellikleri, zihinsel sermaye ve soyut değerlerin stratejik önemi sürekli olarak artmaktadır (Pfeffer, 1994; Pfeffer, 1998). Bu değerler çoğunlukla firmaların bilanço sayfalarında görünmezken, bu sermayenin ana kaynağı olan insan unsuru da arka planda yer almaktadır (Itami, 1987). Bu yüzden birçok firma odaklanmalarını strateji içeriğinden strateji uygulamalarına doğru artan bir şekilde genişletmiştir. Hız, inovasyon ve adapte olabilirlik rekabetçiliği ve kabiliyetleri yansıttğından (Hamel ve Prahalad, 1994), insan kaynaklarının optimum bir dengede kullanımı adına onların huzurlu ve mutlu çalışabileceği bir ortam ile arkadaşları ile ilişkilerindeki güven duygusu büyük önem arz etmektedir.

\subsection{Sözlü Saldırganlık (Verbal Aggressiveness)}

Saldırganlık bir kişilik özelliğidir. Saldırgan ifadelerin kullanıldı̆ı̆ iletişim ise ilgili literatürde agresif iletişim olarak ifadesini bulmaktadır. Bir agresif iletişim türü olan sözlü saldırganlık ise genellikle bireylerin karşısındaki kişiyi hedef alan ve onlara psikolojik acı vermek amacıyla, kişisel haklarına saldırmayı ifade eder(Sabourin, 1996). Saldırgan kişilik yapısındaki bireyler iletişimlerinde daha fazla sözlü ve fiziki saldırganlığa başvurmaktadırlar (Carey ve Mongeau, 1996). Birçok araştırma tarafindan desteklenen görüş, sözlü saldırganlığın yıkıcı bir iletişim türü olduğudur. Kişilerarası iletişimde çok sık karşılaşılan sözlü saldırganlık kontrol altına alınmak maksadıyla daha fazla incelenmek zorundadır (Infante, 1995). Bütün yıkıcı etkisine rağmen sözlü saldırganlık kişilerarası şiddete ve fiziksel saldırganlığa engel olmaktadır (Infante, 1989). Burada kişinin kızgınlığını bir anlamda sözlü olarak dışavurmak suretiyle kendisini yatıştırmasından bahsedilmektedir. Sözlü olarak karşısındaki bireye saldıran kişinin fiziksel şiddete daha az başvurduğu ifade edilmektedir (Carey ve Mongeau, 1996). Tabi ki bu durum da normal iletişim sürecinde istendik bir davranış değildir lakin fiziksel şiddet daha yıkıcıdır. Tartışma ve sözlü saldırgan iletişim muhatap bireylere saldırma bağlamında birbirlerinden ayrılmaktadırlar. Mesela tartş̧ma öğrenmeyi artırmakta, problem çözümünü zenginleştirmekte, yaratıcılığı artırmakta, sosyal bakış açısı geliştirmekte (Johnson ve Johnson, 1979), lider üye etkileşimini artırmakta (Schultz, 1982), iletişim yeteneğini geliştirmekte (Onyekwere, Rubin ve Infante, 1991), örgüt içerisindeki istendik davranışları artırmaktadır (Infante ve Gorden, 1985). Bu duruma zıt olarak ise birçok araştırma sözlü saldırganlık ile negatif ilişki içerisinde olan birçok kavram ortaya koymuştur. Eşler arasındaki sözlü saldırganlığın yol açtı̆̆ı depresyonlar (Segrin ve Fitzpatrick,1992), düşük yaşam tatmini (Payne ve Saborin, 1990), istenmeyen örgüt içi davranışlar (Infante ve Gorden, 1985) gibi. Sözlü saldırganlık bireyin kişisel haklarına saldırırken, tartş̧ma bireyin iletişimdeki pozisyonunu hedef almaktadır (Infante vd., 1989).Nitekim sözlü saldırganlık örgütler içerisinde de kendisini gösteren bir iletişim stilidir. Özellikle yöneticilerin astlarına karşı uyguladıkları bir yöntem olarak belirginleşmektedir. Bu durum hiyerarşinin daha belirgin olduğu örgütlerde örgüt dışından da hissedilir boyutlara ulaşmaktadır (Rancer, 2006). Yöneticilerin sözlü saldırgan iletişim stilinin örgüt içerisinde istendik işgören davranışlarını negatif etkilediği teorik olarak ifade edilmekle birlikte bu konuda yapılmış çok sayıda uygulamalı çalışma bulunmamaktadır. Bu durumun birçok nedeni olabilir lakin en önemli nedenlerinden biri de veri toplama yöntemi olarak kullanılan anket yönteminde, çalışanların iş kaygısı nedeniyle yöneticileri hakkında objektif değerlendirme yapmaktan kaçınmalarıdır. Nitekim örgütler içerisinde veri toplanırken karşılaşılan en önemli sorun çalışanların örtülü bilgiyi verirken kendilerini suç işliyormuş gibi hissetmeleri sıkça karşılaşılan bir durum olarak düşünülmektedir. Yapılan bir çalışmada (Karaca, 2007) mağdurların yöneticileri ile ilgili objektif değerlendirme yapmaktan kaçındıklarına ilişkin bir araştırma bulgusu bulunmaktadır. 


\section{2. Örgütsel Bağılık (Organizational Commitment)}

Örgütsel bağlılık esasen birey ile örgüt arasındaki ilişkiyi temel alan bir kavramdır. Bu kavramı bireyin örgüte ve örgütün de bireye karşı gerçekleştirmesi gereken sorumlulukları çerçevesinde değerlendirmek doğru bir yaklaşımı ifade etmektedir (Çöl, 2004). Örgütsel bağlııkla ilgili çalışmaların ilk aşamalarında kavram, çalışanın örgütüne karşı sadakat duyması, örgütün bir parçası haline gelebilmek adına örgüt değerlerini benimsemesi olarak ifade edilmiştir (Aydemir ve Tak, 2002). Lakin daha sonra yapılan araştırmalarda bağlılı kavramının daha ziyade psikolojik bir tutumu ifade ettiği ve bireylerin örgütün amaçlarına hizmet adına kendilerini örgütle özdeşleştirdikleri ve örgütün menfaatlerini kendi menfaatlerinin üzerinde tuttukları bir duruma dönüşmüştür (Baysal ve Paksoy, 1999; Küçük, 2012). Örgütsel bağlılık bir tutumdur. Bireyin psikolojik olarak kendini örgütüne sadık hissetmesi, örgüt amaç ve hedeflerine hizmet etmesi, örgütün değer yargılarına inanç geliştirmesi ve örgütün paylaşılan vizyonuna katkı sağlamasını ifade etmektedir.

Örgüte karşı bağlıık duyan bir çalışan içsel motivasyonla motive olan emir ve talimatları yerine getirirken gönüllü davranan, başarılı sonuç almak için çaba sarfeden bireylerdir (Balay, 2000). Konu ile ilgili önemli çalışmalardan biri olan Mowday ve arkadaşlarının (1979) yaptığı çalışmada bağlıık, çalışanların örgüt amaç ve hedeflerine inanarak benimsemesi ve örgütün amaçlarını gerçekleştirebilme adına yoğun çaba sarfederek örgüte karşı olumlu duygular beslemesi ve örgüte olan psikolojik sadakatin yükseltilerek örgüt üyeliğini devam ettirme konusunda istekli davranması olarak tanımlanmaktadır (Mowday vd., 1979). Örgüte karşı bağlılık geliştiren bireylerin zaman içerisinde örgütle bütünleşerek kişisel amaçları ile örgütsel amaçları birleştirdiği bilinmektedir. Bu nokta örgüt açısından oldukça olumlu ve beşeri sermayenin korunması açısından da rekabet üstünlüğü oluşturan bir durumdur. Örgütlerin bireyler üzerindeki etkinliğini de artıran bağlıık kavramı bireyin kendisini daha huzurlu ve çalışma yaşamını daha barışçı hissetmesine neden olmaktadır. Daha önceleri sadakat ve işte kalma niyeti gibi konularla birlikte anılan bağııık kavramı bu iki kavramın toplamından daha fazla anlam ifade etmektedir (Hall vd., 1970; Rusbult ve Farrel, 1983).

Örgütsel bağlılı̆ı̆n normatif bağ|ılık, devam bağ|ılığı ve duygusal bağlılık olmak üzere üç alt boyutu bulunmaktadır. Normatif bağlılık bireylerin örgütsel amaç ve hedeflere inanarak örgütsel kural ve normlara olan bağ|ıı̆̆ını ifade etmektedir. Devam bağlılığı bireyin örgütteki üyeliğini devam ettirme konusundaki aşırı istek ve arzusunu ifade etmektedir. Duygusal bağlılık ise bireyin örgüt için ekstra rol davranışlarında bulunmasını, diğergam ve sivil erdem sahibi davranışlar sergilemesini ifade etmektedir (Meyer ve Allen, 1990).

\subsection{Algılanan Çalışma Arkadaşları Desteği (Perceived Peer Support)}

Algılanan çalışma arkadaşları desteği özünde bir işyeri desteği türüdür. İ̧̧ yeri desteği olarak ifade edilen kavram; örgütsel desteği, yönetici desteğini ve çalışma arkadaşları desteğini kapsayan sosyal destekler bütünüdür. Bu bağlamda kısaca örgütsel destek ve yönetici desteğine değinmek gerekir. Örgütsel destek, çalışanların, örgüt için gösterdikleri çaba, bağlılık ve ekstra rol davranışları karşıı̆ı̆nda, örgüt tarafindan verilen maddi ödülleri ve onaylanma, takdir edilme ve saygı görme gibi manevi ödülleri kazanmalarını ifade etmektedir. Algılanan örgütsel destek kurumsal bir durumu ifade etmektedir. Yani örgütün tüzel kişiliği ya da kurumsal kişiliği tarafindan verilen destek olarak düşünülmelidir (Eisenberger vd., 1986, 2002;Giray, 2013; Ng ve Feldman, 2012).

Algılanan yönetici desteği, çalışanın hiyerarşik olarak bağlı bulunduğu ilk kademe yöneticisinden algıladığı desteği ifade etmektedir (Giray, 2013; Rhoades vd., 2001; Yoon ve Lim, 1999). Bu destek, yöneticinin çalışanına karşı dostça, kardeş̧̧e ve babacan tavırlarını içermektedir. Yönetici tarafindan gösterilen yakın ilişki stilinin çalışan üzerinde bıraktığı olumlu izlenimi ifade etmektedir (Pearce vd., 1994). Çalışma arkadaşları desteği ise çalışanın aynı hiyerarşik düzeyde birlikte çalıştı̆̆ kişilerden algıladığı desteği ifade etmektedir (Yoon ve Lim, 1999). Daha detaylı bir ifadeyle, örgüt içerisinde aynı hiyerarşik kademede, benzer statüde, aynı görev ve rolleri üstlenen kişilerden algılanan destek olarak belirtilebilir.

Algılanan çalışma arkadaşları desteğinin kapsamı, bireyin gününün büyük bir bölümünü birlikte geçirdiği iş arkadaşlarııı sevecen, yardımsever, diğergam, özgeci ve işyeri nezaketi çerçevesindeki davranışlarını içermektedir (Mead, Hilton ve Curtis, 2001). Çalışma arkadaşları desteği kavramı daha çok stres, 
gerginlik gibi işle bağlantlı ama kişinin sağlık durumunu etkileyen konuları inceleyen çalışmalarda ele alınmıştır (Giray, 2013). Nitekim kavram daha ziyade zihinsel sağlıkla ilişkilidir. Bundan kasıt bireyin psikolojik olarak yaşadığı insani ve iletişimsel süreçlerin kendisine yansımasıdır. Burada dikkat edilmesi gereken husus, bireyin gerginlik kaynakları iş stresi, mesleki stres ya da iletişim çatışmaları gibi kişisel stresörler de olabilmektedir. Bireyin kişilik yapısı da bir tür gerginlik sebebi olabilir (Mead, Hilton ve Curtis, 2001). il gili yazın incelendiğinde, algılanan çalışma arkadaşları desteği, diğer işyeri destekleri olan algılanan örgütsel destek ve algılanan yönetici desteği kadar çok sayıda uygulamalı çalışmaya konu edilmemiştir.

Özellikle çalışma arkadaşları desteği kavramının öncülleri ve sonuçlarına ilişkin yapılan çalışma sayısı inmal edilebilir düzeydedir (Giray, 2013). Eder ve Eisenberger (2008) tarafindan yapılan bir çalışmada, kişinin çalışma arkadaşları işe geç gelme gibi geri çekilme davranışları sergilediğinde, çalışanın da bu davranışları sergilemeye eğilimli olduğu belirlenmiştir (Giray, 2013). Bu bir tür gruba uyma davranışı olabilir ve ilgili çalışmanın sonuçlarına göre kişi çalışma arkadaşlarından etkilenmekte ve onları etkileyebilmektedir. Yapılan bir çalışmada, çalışma arkadaşlarından gelen sosyal destek ile çalışanların kariyerlerine bağlııkları arasında olumlu yönde bir ilişki olduğu ve çalışma arkadaşlarından destek gören kişilerin iş stresinin olumsuz yönlerinden daha az etkilendikleri görülmüştür. Ayrıca başka bir çalışmada ise çalışma arkadaşları desteği ile çalışanın gerginliği arasında negatif yönlü güçlü korelasyonlar tespit edilmiştir (Ducharme, Knudsen ve Roman, 2008; Fenlason ve Beehr, 1994'ten Giray, 2013).Yapılan bir meta-analiz çalışmasında ise, çalışma arkadaşları desteğinin duygusal bağııık ile olumlu, işten ayrılma niyeti ile olumsuz yönde anlamlı ilişkiye sahip olduğu saptanmıştır (Ng ve Sorenson, 2008'den Giray, 2013).

Araştırmanın amacı, örgüt içerisinde yöneticilerin kullandığı sözlü saldırgan ifadelerin örgüt çalışanlarının örgütsel bağııık düzeyleriyle olan ilişkisinde çalışanların iş arkadaşlarından algıladığı sosyal desteğin aracılık rolünü tespit etmektir. Böylelikle yöneticinin sözlü saldırganlığının bireyin örgütsel bağııı̆ına etkisi, bireyin algılanan arkadaş desteğinin örgütsel bağııı̆ı̆ına etkisi ve sözlü saldırganlığın algılanan arkadaş desteğine etkisi de tespit edilmiş olacaktır.

Sözlü saldırganlığın örgütsel bağlılığa etkisinde algılanan arkadaş desteğinin aracılık rolünün incelenmesi amacıyla oluşturulan hipotezler kapsamında yapılandırılan araştırma modeli Şekil 1'de görüldüğü gibidir.

Şekil 1. Araştirma Modeli

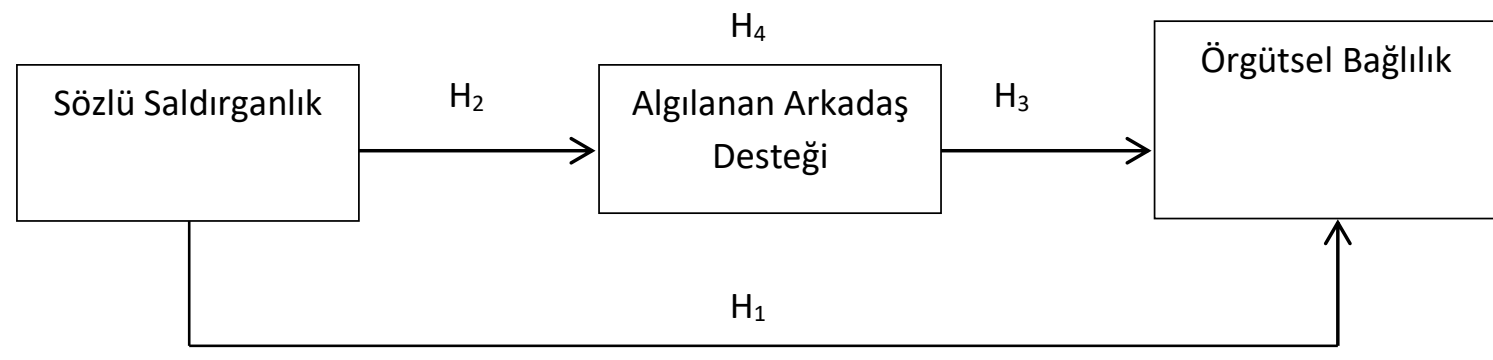

Bu çerçevede araştırmanın hipotezleri şu şekilde oluşmaktadır:

Hipotez 1: Sözlü saldırganlığın örgütsel bağlııı üzerinde etkisi vardır.

Hipotez 2: Sözlü saldırganlığın algılanan arkadaş desteği üzerinde etkisi vardır.

Hipotez 3:Algılanan arkadaş desteğinin örgütsel bağlılık üzerinde etkisi vardır.

Hipotez 4: Sözlü saldırganlığın örgütsel bağlılık üzerindeki etkisinde algılanan arkadaş desteğinin aracılık rolü vardır. 


\section{Araştırmanın Metodolojisi}

\subsection{Araştırmanın Değişkenleri}

Araştırmanın değişkenleri üç grup olarak ele alınmıştır. Illk grupta sözlü saldırganlık davranışlarını ve iletişim düzeyini tespit etmeye yönelik ifadelerin yer aldığı sözlü saldırganlık değişkeni bulunmaktadır. íkinci grupta örgüt çalışanlarının örgüte olan bağlılık düzeyini tespit etmeye yönelik örgütsel bağlılık ifadeleri yer almaktadır. Üçüncü grupta ise örgütte çalışan bireylerin algıladıkları arkadaş desteği düzeyini tespit etmeye yönelik algılanan arkadaş desteği ifadeleri bulunmaktadır. Bu çalışmada demografik değişkenler analize tabi tutulmamış olup ayrı bir çalışmanın konusu olarak ileriye bırakılmıştır. Çalışmanın sözlü saldırganlık ifadelerinin oluşturduğu sözlü saldırganlık düzeyi bağımsız değişkendir. Örgütsel bağlılık düzeyi ise araştırmanın bağımlı değişkenidir. Algılanan arkadaş desteği düzeyi ise aracı değişken olarak analize tabi tutulmuştur.

\subsection{Veri Toplama Yöntemi ve Örneklem}

Araştırmada veri toplama yöntemi olarak anket yöntemi kullanılmıştır. Anket formu başka çalışmalarda kullanılan ölçekler yardımıyla tarafimızca oluşturulmuş ve pilot uygulaması yapıldıktan sonra kullanılmaya başlanmıştı. Anket formu 4 kısımdan oluşmaktadır. İlk kısımda demografik bilgiler, ikinci kısımda sözlü saldırganlık ifadeleri, üçüncü kısımda örgütsel bağlılık ifadeleri ve son kısımda algılanan arkadaş desteği ifadeleri yer almaktadır. Araştırmanın evrenini Kazakistan Sağlık Bakanlığı'na bağı sağıık kuruluşlarında çalışan 4632 yardımcı sağlık personeli oluşturmaktadır. Bu evren içerisinden olasıııksız örnekleme yöntemlerinden olan kolayda örnekleme yöntemiyle seçilen 2001 kişiye anket formu ulaştırılmış ve 1889 anket formu geri toplanmıştır. Çeşitli nedenlerle geçersiz sayılan anket formları elimine edildikten sonra 1265 anket formu değerlendirmeye alınmıştır.

\subsection{Araştırmanın Ölçekleri}

Bireylerin sözlü saldırganlıklarını tespit etmek amacıyla, Rancer ve Avtgis (2006) tarafindan geliştirilen 10 ifadeli 5'li likert tipi ölçek kullanılmıştr. Ölçeğin kullanımı ilgili yazında bir çok araştırmada yaygındır. Örgütsel bağlılık düzeyini tespit etmek amacıyla, Meyer ve Allen (1990) tarafindan geliştirilen 3 alt boyut ve 18 ifadeden oluşan $5^{\prime}$ li likert tipi ölçek kullanılmıştır. Ölçek geçerlilik ve güvenilirlik katsayısı yüksektir. Algılanan iş arkadaşları desteği düzeyini tespit etmek için Caplan vd. (1975) tarafindan geliştirilen ölçek 4 ifadeden oluşmaktadır. 5'li likert tipi ölçeğin ilgili yazında kullanımı yaygındır.

\subsection{Güvenilirlik Testi Sonuçları}

Araştırmanın amacı doğrultusunda oluşturulan hipotezlerin test edilmesine geçilmeden önce verilerin güvenilirlik ve geçerlilik açısından değerlendirilmesi gerekmektedir. Bu sebeple, araştırma hipotezi test edilmeden önce güvenilirlik ve geçerlilik analizleri yapılmış, ölçeklerin güvenilirlikleri içsel tutarlılık yöntemi ile belirlenmiştir.

İçsel tutarlılık yönteminin bir uygulaması da "alfa katsayısı"dır. Alfa katsayısı ölçeğin güvenilirliğini test etmede en yaygın kullanılan yöntem olup, sıfır ve bir arasında değişen rakamlar alır. Araştırmada kullanılan ölçeğin de güvenilirliğinden bahsedebilmek için alfa katsayısının 0,70 ve üzerinde olması gerekmektedir (Hair vd., 1998).

\subsection{Bulgular}

Araştırma kapsamında kullanılan ölçeklerin güvenilir olduğunun tespit edilmesinden sonra verilerin ortalamaları, standart sapmaları hesaplanmış ve değişkenler arasındaki korelasyon değerleri incelenmiştir. Değişkenlere ilişkin ortalama, standart sapma ve değişkenler arasındaki korelasyonlar Tablo 1'de verilmektedir. 
M. Karaca

Tablo 1. Değişkenlere Ait Ortalama, Standart Sapma ve Korelasyon Değerleri

\begin{tabular}{llllll}
\hline Değişkenler & Ort. & SS & $\mathbf{1}$ & $\mathbf{2}$ & $\mathbf{3}$ \\
\hline 1-Sözlü Saldırganlık & 2.89 & .58 & - & & \\
\hline 2-Örgütsel Bağııık & 3.01 & .49 & $.278^{*}$ & - \\
\hline 3-Algılanan Arkadaş Desteği & 3.72 & 1.25 & $.107^{*}$ & $.204^{*}$ & - \\
\hline$p<.001$ & & &
\end{tabular}

Araştırmada değişkenler arasındaki ilişkilerin tespit edilmesinde korelasyon analizi kullanılmıştır. Korelâsyon analizi pazarlama araştırmalarında yaygın olarak kullanılmaktadır. Doğrusal ilişkileri ortaya çıkarmaya yarayan bu analiz katsayısı -1 ile +1 arasında değişen bir değeri temsil etmektedir.

Illgili tablo incelenecek olur ise sözlü saldırganlık ile hem örgütsel bağlılık ( $r=.278 ; p<.001)$ hem de algılanan arkadaş desteği ( $r=.107 ; p<.001)$ arasında anlamlı düzeyde bir ilişki olduğu gözlenmiştir. Ayrıca, yine örgütsel bağlılık ve algılanan arkadaş desteği arasında da anlamlı bir ilişkinin ( $r=.204 ; p<.001$ ) olduğunu ifade etmek mümkündür. İlave olarak ortalama bazında bir inceleme yapılır ise algılanan arkadaş desteğinin (ort=3.72) en yüksek düzeyde olduğu tespit edilmiştir.

\section{Hipotez Testleri}

Araştırmanın hipotezlerinin test etmek amacıyla çalışmada hiyerarşik regresyon analizi kullanılmıştır. Sonuçlar aşağıda sunulan Tablo-2'de verilmektedir.

Tablo 2. Regresyon Analizi Sonuçları

\begin{tabular}{|c|c|c|c|c|c|c|c|c|}
\hline Değişkenler & Beta & $\mathrm{t}$ & Sig. & $\mathrm{R}$ & $\mathrm{R}^{2}$ & $\mathrm{~F}$ & Sig.F & Sonuç \\
\hline \multicolumn{9}{|c|}{$H_{1}$ : Sözlü saldırganlığın örgütsel bağlılık üzerinde etkisi vardır. } \\
\hline Sözlü Saldırganlık & .278 & 10.272 & .000 & .278 & .077 & 105.519 & .000 & Kabul \\
\hline \multicolumn{9}{|c|}{$H_{2}$ : Sözlü saldırganlığın algılanan arkadaş desteği üzerinde etkisi vardır. } \\
\hline Sözlü Saldırganlık & .107 & 3.816 & .000 & .107 & .011 & 14.565 & .000 & Kabul \\
\hline \multicolumn{9}{|c|}{$H_{3:}$ Algılanan arkadaş desteğinin örgütsel bağlıık üzerinde etkisi vardır. } \\
\hline Algılanan Arkadaş Desteği & .204 & 7.376 & .000 & .204 & .041 & 54.406 & .000 & Kabul \\
\hline
\end{tabular}

Yukarıda verilen tablo sonuçları incelenecek olur ise çalışmanın amacı doğrultusunda oluşturulan tüm hipotezleri destekler nitelikte sonuçlar elde edilmiştir. Yani, ilk hipotez kapsamında sözlü saldırganlığın örgütsel bağlıık ( $\beta=.278 ; p<.001)$ ve algılanan arkadaş desteği $(\beta=.107 ; p<.001)$ üzerinde anlamlı bir etkisinin olduğu; ayrıca algılanan arkadaş desteğinin de örgütsel bağ|ıık üzerinde $(\beta=.204 ; p<.001)$ anlamlı düzeyde etkisinin olduğu tespit edilmiştir.

Son hipotez olan aracı etkiyi inceleyen hipotez için tespit edilen bulgularda aşağıdaki Tablo 3'te verilmektedir.

Tablo 3. Aracı Değişken Analizi

\begin{tabular}{|c|c|c|c|}
\hline \multirow[b]{2}{*}{ Değişkenler } & \multicolumn{3}{|c|}{ Algılanan Arkadaş Desteği (AAD) } \\
\hline & Model $1(\beta)$ SS-AAD & Model 2a ( $\beta$ ) SS-ÖB & Model 3a ( $\beta)$ SS/AAD-ÖB \\
\hline Sözlü Saldırganlık (SS) & $.107^{*}$ & $.278^{*}$ & $.259 *$ \\
\hline Örgütsel Bağlılık(ÖB) & & & $.176^{*}$ \\
\hline $\mathrm{R}^{2}$ & .011 & .076 & .108 \\
\hline $\mathrm{R}^{2}$ 'deki Değişim & .011 & .077 & .031 \\
\hline F'deki Değişim & 14.565 & 105.519 & 43.091 \\
\hline
\end{tabular}


Tablo-3'de sonuçları sunulan hiyerarşik regresyon analizlerine göre; sözlü saldırganlığın örgütsel bağlıık ile olan ilişkisinde algılanan arkadaş desteğinin aracı değişken (mediating) olarak ( $\beta=.176 ; p<$. 001) etkide bulunduğu ve arkadaşlık desteğinin örgütsel bağlılık üzerindeki sözlü saldırganlığın etkisini azalttğı ( $\beta=$ .259; $p<$.001) tespit edilmiştir. Son aşamada sözlü saldırganlığın örgütsel bağlılığa olan etkisinin de anlamlı olması, bu modelde örgütsel politik algılamaların kısmi aracı değişken (Baron ve Kenny, 1986; MacKinnon vd., 2002) olarak modelde yer aldığını vurgulamaktadır.

Aracılık etkisi, aracı değişkenin varlığının, bağımlı değişken üzerinde bağımsız değişkenin direkt etkisini azaltırsa mevcut olabilir. Aracılık etkisinin anlamlılığını test etmek için çok sayıda yöntem mevcuttur. Bu çalışmada aracılık etkisinin anlamlıı̆ıını test etmek için Sobel testinden yararlanılmıştı. Sobel testinde z değeri, $\alpha=.05$ düzeyinde +1.96 'nın kritik değerlerini aştı̆ı zaman, bir aracılık etkisinin var olmadığını belirten sifir hipotezi reddedilmektedir.

Bu çalışmada algılanan arkadaşık desteğinin dolaylı etkisinin anlamlılı̆ı̆na ilişkin Hayes' PROCESS makrosu kullanılarak yapılan Sobel testi sonucu istatistiksel olarak anlamlıdır ( $Z=5.11 p<.001)$. Sobel testi istatistiksel olarak anlamlı olduğu için dolaylı etkinin anlamlı bir şekilde sıfirdan farklılaştiğı sonucu çıkarılabilir. Bu bulgu Hipotez 4'ü desteklemektedir.

\section{Sonuç ve Tartş̧ma}

Bu araştırma ile algılanan arkadaş desteğinin aracı etkide bulunduğu bir durumda sözlü saldırganlığın örgütsel bağlılık üzerindeki etkisi incelenmiştir. Yapılan analizler neticesinde mevcut çalışma kapsamında kurulan hipotezlerin tamamını destekler nitelikte sonuçlar elde edilmiş olup; sözlü saldırganlığın hem örgütsel bağlıık hem de algılanan arkadaş desteği üzerinde anlamlı düzeyde bir etkide bulunduğu, ayrıca algılanan arkadaş desteğinin de sözlü saldırganlık ve örgütsel bağlılık ilişkisinde kısmi aracı role sahip olduğu tespit edilmiştir.

Örgütler için insan bir kaynaktır. Özellikle örgüt içerisindeki insanların mutlu bir çalışma yaşamına sahip olmaları için yoğun çaba sarf eden örgütsel davranış bilimi, örgüt içindeki insanın örgüt ortamındaki ilişkilerini araştırmakta ve örgütsel amaçlarla kişisel amaçları bütünleştirecek argümanlar geliştirmeye çalışmaktadır. Bu bağlamda örgüt içerisindeki sözlü saldırganlığın bireylerin örgüte karşı olumlu tutumlarını yaraladığı düşünülmektedir. Özellikle hiyerarşi-yoğun örgütlerde yönetici tarafindan takınılan bu tavır örgütsel ahengi bozabilmekte ve çalışma yaşamının kalitesini azaltıcı bir rol oynayabilmektedir.

Bu çalışma ile yöneticilerin sözlü saldırgan davranışlarının çalışanların örgüte olan bağlığı üzerindeki etkisi, bu etkinin aracı değişkeni olarak çalışanların iş arkadaşlarından algıladıkları sosyal desteğin rolü tespit edilmektedir. Örgüte olan bağlılığın beşeri sermayenin temini ve korunması noktasında hayati öneme sahip olduğu düşünülürse çalışma yaşamının kalitesi ve örgütlerin rekabet üstünlüğü elde etmesinde önemli bir noktanın açığa çıkarılacağı düşünülmektedir. Bireylerin örgütlerine karşı geliştirdikleri olumlu tutumların devamı ve yeni olumlu tutumların geliştirilmesi önemlidir. Lakin önce mevcudu korumak adına pozitif örgütsel tutumları zedeleyici davranışların tespit edilmesi ve ortadan kaldırılması daha da önem arz etmektedir.

Ancak, çalışmanın sadece kamu kurumunda yapılmış olması ve örneklemdeki olası kültür etkilerinin ihmal edilmesi nedeniyle çalışmanın genellenebilmesi adına ilave çalışmaların yapılması gerektiği ortadadır. íkinci olarak, mevcut çalışmada bütçe ve zaman kısıtlaması nedeniyle tek düzeyli ve tek zamanlı bir veri toplama yöntemi uygulanmıştır. İlave olarak çalışmanın sadece kamuda ve hastane çalışanları ile yapılması bir kısıtlıık oluşturmaktadır. Belirtilen bu unsurların çalışmanın zayıf yönleri arasında olacağı ifade edilebilir.

Sözlü saldırganlık konusu örgütsel davranış alanında pek ele alınmamış ve keşfedilmemiş bir konu olarak gözükmektedir. Bu çalışma alanında Kazakistan'da neredeyse yok denecek kadar az sayıda çalışma söz konusudur. Bu yüzden, gelecek çalışmaların bu alanda yapılmasının ilgili literatüre önemli katkılar sağlayacağı değerlendirilmektedir.

Illave olarak bu çalışmadaki algılanan arkadaş desteğinin algılanan örgütsel destek kapsamında aile veya amir desteği şeklinde de yeni aracı değişkenler ile tekrar incelemeye alınmasının iş-yaşam dengesi açısından da mutlu ve huzurlu bireyler ortaya çıkarma adına önemli olduğu düşünülmektedir. 


\section{Son Notlar}

1. Yazar çalışmanın anket uygulamasında gereken yardımı sağlayan Kazakistan - Astana Yunus Emre Enstitüsü Okutmanı Ahmet Şahin'e teşekkür eder.

\section{Kaynaklar}

Allen, N. J., \& Meyer, J. P. (1990). The measurement and antecedents of affective, continuance and normative commitment to the organization. Journal of Occupational Psychology, 63(1), 1-18.

Balay, R. (2000). Özel ve resmi liselerde yönetici öğretmenlerin örgütsel bağlılığı: Ankara ili örneği. Ankara Üniversitesi Sosyal Bilimler Enstitüsü, Basılmamış Doktora Tezi, Ankara.

Baron, R.M., \& Kenny, D.A. (1986). The moderator- mediator variable distinction in social psychological research: Conceptual, strategic, and statistical considerations. Journal of Personality and Social Psychology, 51, 1173-1182.

Baysal, A. C., \& Paksoy, M. (1999). Mesleğe ve örgüte bağlılığın çok yönlü incelenmesinde Meyer-Allen modeli. İstanbul Üniversitesi İşletme Fakültesi Dergisi, 1(28), 7-15.

Caplan, R. D., Cobb, S., \& French, J. R. (1975). Job demands and worker health: Main effects and occupational differences. In Hew Publication (NIOSH), Vol. 75. DHEW.

Carey, CM., \& Mongeau, P.A. (1996). Communication and violence in courtship relationships.In D.D. Cahn \& S.A. Lloyd (Eds.), Family Violence from A Communication Perspective. 127-150. Thousand Oaks, CA: Sage.

Celles, R. J. (1974). Vie violent home, Beverly Hills, CA: Sage.

Coyle-Shapiro, J.A.M., \& Conway, N. (2005). Exchange relationships: Examining psychological contracts and perceived organizational support. Journal of Applied Psychology, 90, 774-781

Çöl, G. (2004). Güçlendirme ve örgütsel bağlılık ilişkisi üzerine bir araştırma. Gebze Teknik Üniversitesi Sosyal Bilimler Enstitüsü, Basılmamış Doktora Tezi, Kocaeli.

Ducharme, L. J., Knudsen, H. K., \& Roman, P. M. (2008). Emotional exhaustion and turnover intention in human service occupations: The protective role of coworker support. Sociological Spectrum, 28, 81-104.

Eder, P., \& Eisenberger, R. (2008). Perceived organizational support: Reducing the negative influence of coworker withdrawal behavior. Journal of Management, 34, 55-68.

Eisenberger, R., Armeli, S., Rexwinkel, B., Lynch, P. D., \& Rhoades, L. (2001). Reciprocation of perceived organizational support. Journal of Applied Psychology, 86-1, 42.

Eisenberger, R., \& Adornetto, M. (1986). Generalized self-control of delay and effort. Journal of Personality and Social Psychology, 51-5, 1020.

Eisenberger, R., Stinglhamber, F., \& Vandenberghe, C. (2002). Perceived supervisor support: Contributions to perceived organizational support and employee retention. Journal of Applied Psychology, 87-3.

Fenlason, K. J., \& Beehr, T. A. (1994). Social support and occupational stress: Effects of talking to others. Journal of Organizational Behavior, 15, 157-175.

Giray, D.M. (2013). İş yeri desteği: Örgüt, yönetici ve çalışma arkadaşları desteğine genel bir bakış. İş - Güç Endüstri ilişkileri ve Insan Kaynakları Dergisi, 15(3), 65-81.

Hall, D. T., Schneider, B., \& Nygren, H. T. (1970). Personal factors in organizational Identification, Administrative Science Quarterly, 176-190.

Hamel, G., \& Prahalad, C.K. (1994). Competing for the future. Harvard Business School Press.

Hofer, C., \& Schendel, D. (1978). Strategy formulation: Analytical concepts. West Publishing, St. Paul, MN

Infante, D. A. (1988). Arguing constructively, prospect heights. IL: Waveland Press.

Infante, D. A. (1995). Teaching students to understand and control. Verbal Aggression Communication Education, 44,5143.

Infante, D. A., Chandler, T. A., \& Rudd, J. E. (1989). Test of an argumentative skill deficiency modal of ınterspousai violence. Communication Monographs, 56,163-177.

Infante, D. A., \& Gorden, W. I. (1991). How employeessee the boss: Test of an argumentative and affirming model of superiors' communicative behavior. Western Journal of Speech Communication, 55, 294-305. 
Infante, D. A., \& Rancer. A. S. (1982). A Conceptualization and measure of argumentativeness. Journal of Personality Assessment, 46, 72-80.

Infante, D.A., \& Rancer, A.S. (1996). Argumentativeness and verbal aggressiveness: A review of recent theory and research. Communication Yearbook, 19, 319-351

Jahn, E., Thompson C.A., \& Kopelman R.E. (2003). Rationale and construct validity evidence for a measure of Perceived Organizational Family Support (POFS): Because purported practices may not reflect reality. Community, Work and Family, 6, 123-140.

Johnson, D. W., \& Johnson, R. T. (1979). Conflict in the classroom: Controversy and learning. Review of Educational Research, 49,51-70.

Küçük, M. (2012). Kariyer yönetimi ve örgütsel bağlılık arasındaki ilişki: Banka çalışanları üzerindeki etkinin incelenmesi. Çanakkale Onsekiz Mart Üniversitesi Sosyal Bilimler Enstitüsü, Basılmamış Yüksek Lisans Tezi, Çanakkale.

Lambert, S.J. (2000). Added benefit: The link between work-life benefits and organizational citizenship behavior. Academy of Management Journal, 43, 801-815.

MacKinnon, D. P., Lockwood, C. M., Hoffman, J. M., West, S. G., \& Sheets, V. (2002). A comparison of methods to test mediation and other intervening variable effects. Psychological Methods, 7-1, 83.

Mead, S., Hilton, D., \& Curtis, L., (2001). Peer support: A theoretical perspective. Psychiatric Rehabilitation Journal, 252, 134.

Mowday, R. T., Steers, R. M., \& Porter, L. W., (1979). The measurement of organizational commitment. Journal of Vocational Behavior, 14-2, 224-247.

Ng, T. W. H., \& Sorenson, K. L., (2008). Toward a further understanding of the relationships between perceptions of support and work attitudes: A meta-analysis. Group and Organization Management, 33, 243-268.

Ng, T.W.H., \& Feldman D.C., (2012). Employee voice behavior: A meta analytic test of the conservation of resources framework. Journal of Organizational Behavior, 33, 216-234.

Onyekwere, E. O., Rubin, R. B., \& Infante, D. A. (1991). Interpersonal perception and communication satisfaction as a function of argumentativeness and ego-ınvolvement. Communication Quarterly, 39, 35-47

Payne, M. J., \& Sabourin, T. C. (1990). Argumentative skill deficiency and its relationship to quality of management. Communication Research Reports, 7, 121-124.

Pearce, J.L., Branyiczki, I., \& Bakacsi, G., (1994). Person-based reward systems: A theory of organizational reward practices in reform-communist organizations. Journal of Organizational Behavior, 15, 3, 261-282.

Pfeffer, J. (1994). Competitive advantage through people. Boston: Harvard Business School

Pfeffer, J. (1998). The human equation. Boston: Harvard Business School

Porter, M. (1985). Competitive advantage. Free Press, New York.

Rancer, A. S., \& Avtgis, T. A. (2006). Argumentative and aggressive communication: Theory, research, and application. Sage Publications.

Rancer, A.S., Baukus, R.A., \& Amato, P.A. (1986). Argumentativeness, verbal aggressiveness, and marital satisfaction. Communication Research Reports,3, 28-32

Rhoades, L., Armeli, S., \& Eisenberger, R., (2001). Affective Commitment to the organization: The contribution of perceived organizational support. Journal of Applied Psychology, 86-5, 825- 836.

Robinson S.L. (1996). Trust and breach of the psychological contract. Administrative Science Quarterly, 41, 514-519.

Rusbult, C. E., \& Farrell, D. (1983). A longitudinal test of the investment model: The impact on job satisfaction, job commitment, and turnover of variations in rewards, costs, alternatives, and investments. Journal of Applied Psychology, 68-3, 429.

Sabourin, T.C. (1996). The role of communication in verbal abuse between spouses. In D.D. Cahn \& S.A. Lloyd (Eds.), Family Violence From A Communication Perspective, 199-217. Thousand Oaks, CA: Sage.

Schrodt, P., \& Lawrence, R. W. (2001). Aggressive coinmunication and Informational reception apprehension: The Influence of listening anxietyand Intellectual inflexibility on trait argumentativeness and verbal aggressiveness. Communication Quarterly, 49 -1, 53-69.

Schultz, B. (1982). Argumentativeness: Its effect in P U P decision-making and its role in leadership perception. Communication Quarterly, 30, 366-375.

Segrin, C., \& Fitzpatrick, M. A. (1992). Depression and verbal aggressiveness in different marital couple types. Communication Studies, 43, 79-91. 
Shalley, C., Gibson, L., \& Blum, T. (2004). Matching creativity requirements and the work environment: Effects on satisfaction and intentions to leave. Academy of Management Journal, 43-2, 215-223

Stinglhamber, F., \& Vandenberghe, C. (2003). Organizations and supervisors as sources of support and targets of commitment: a longitudinal study. Journal of Organizational Behavior, 24, 251-270.

Tak, B., \& Aydemir, A. (2002). İş tasarım sistemi, örgütsel bağlılık ve çalışanların stratejik oryantasyon düzeyi arasındaki etkileşimin incelenmesine yönelik bir model geliştirme çalışması. 10. Ulusal Yönetim ve Organizasyon Kongresi Bildiri Kitabı, Akdeniz Üniversitesi İktisadi ve İdari Bilimler Fakültesi Yayınları.

Tsui, A. S., Pearce, J. L., Porter, L. W., \& Tripoli, A. M. (1997). Alternative approaches to the employee-organization relationship: Does investment in employees pay off? Academy of Management Journal, 40-5, 1089-1121.

Wayne, S.J., Shore, L.M., \& Liden, R.C. (1997). Perceived organizational support and leader-member exchange: A social exchange perspective. Academy of Management Journal, 40, 82-111.

Yoon, J., \& Lim, J. C. (1999). Organizational support in the workplace: The case of korean hospital employees. Human Relations, 52-7, 923-945. 
This Page Intentionally Left Blank 